\title{
A WORLD OF FINS AND FENCES: AUSTRALIAN AND SOUTH AFRICAN SHARK MANAGEMENT IN THE TRANSOCEANIC SOUTH'
}

MILES POWELL

\section{Abstract}

This paper examines the world's two oldest and largest national shark control programs, those of South Africa and Australia. Officials from these two countries have spent more than a century trying to dictate the movement and behaviour of sharks to improve bather safety. To this end, people have deployed technologies ranging from barriers, to nets, to drum lines and even to electrical fields and depth charges. This essay treats these programs as prime examples of the enduring, perhaps inescapable, tensions between mobile nature and the real and imagined boundaries with which we seek to control and administer it. This topic reveals important new dimensions to trans-boundary environmental history. First, this story highlights the need for environmental histories that consider vast (even transoceanic) scales, while simultaneously maintaining attention to local contexts. Second, bather safety programs provide a useful case study for exploring how efforts to control nature have historically intersected with attempts to discipline and regulate humans. Third, this history demonstrates how changing perceptions of nature and predators have forced policymakers to alter the placement and enforcement of barriers that structure interactions between the human and non-human worlds.

Keywords: Australia, South Africa, environmental history, trans-boundary, transnational, international, fence, border, mobility, shark, marine, oceans, predators, beaches, safety, swimming, surfing, conservation, environmentalism, ecology, fisheries, race, ethnicity, gender, Apartheid

In early 2014, Western Australia's state government incurred the wrath of shark advocates and marine conservationists around the world by implementing a controversial shark cull intended to reduce the probability of attacks at local beaches. State Premier Colin Barnett instigated the policy in the wake of an unusual surge in fatal shark encounters. These had claimed the lives of seven people

1 This paper's title alludes to William Cronon's classic study of settler colonists' efforts to impose order on a fluid environment, 'A World of Fields and Fences', the seventh chapter of his path-breaking work, Changes in the Land: Indians, Colonists, and the Ecology of New England (New York: Hill and Wang, 2003). 
in Western Australian waters between August 2010 and November 2013. Under the new program, fisheries agents suspended baited hooks from floating barrels, or 'drums', anchored off popular bathing sites. Inspectors visited the 'drum lines' regularly, killing any captured bull, tiger or white (often called 'great white') shark measuring more than $3 \mathrm{~m}$ in length, and releasing the others-although critics contended that most of the freed sharks likely perished anyway. ${ }^{2}$ The trial run lasted from January through April, and involved the capture of 170 sharks, with 50 of the largest facing destruction. ${ }^{3}$ The Western Australian government hoped to continue this policy for three years. But in the wake of international condemnation, and mass protests within Australia, the state's Environmental Protection Agency terminated the initiative. ${ }^{4}$

This cull was unusual for the opposition it sparked. Yet in other respects, this program simply marked a continuation of a long history of policymakers trying to find ways to mark off some waters as shark-free zones where humans could recreate free from fear of looming dorsal fins. This paper examines the world's two oldest and largest national shark control programs, those of South Africa and Australia. Officials from these two countries have spent more than a century trying to dictate the movement and behaviour of sharks. To this end, people have deployed technologies ranging from barriers, to nets, to drum lines and even to electrical fields and depth charges. Numerous approaches and methods inform my analysis. But I frame this discussion around the enduring, perhaps inescapable, tensions between mobile nature and the real and imagined boundaries with which we seek to control and administer it.

Because environmental historians study subjects—such as plants, animals, rivers or pollutants - that rarely heed political borders or property boundaries, we have been quick to embrace the idea of trans-boundary or transnational history. In multiple studies, we have explored the ways that mobile nature transcends the artificial lines with which we seek to, in the words of James Scott, make the world 'legible'. In so doing, scholars such as Samuel Truett, Kurkpatrick Dorsey, Joseph E. Taylor III, Mark Fiege, Lissa Wadewitz and Mary E. Mendoza have vastly expanded

2 Clarissa Sebag-Montefiore, 'A shark cull divides a nation', BBC News, 10 April 2014. www.bbc.com/news/ magazine-26937924, accessed 6 May 2015.

3 'More than 170 sharks caught under Australia cull policy', BBC News, 7 May 2014. www.bbc.com/news/ world-asia-27304580, accessed 6 May 2015.

4 'Shark cull in Western Australia blocked by regulator', BBC News, 12 September 2014. www.bbc.com/news/ world-asia-29170035, accessed 6 May 2015.

5 James C. Scott, Seeing Like a State: How Certain Schemes to Improve the Human Condition Have Failed (New Haven, CT: Yale University Press, 1998), 11, 138. 
our understanding of intertwined human and natural histories. Their research reveals a world far more fluid and interconnected than conventional state-centred narratives can convey. ${ }^{6}$

The history of shark management connects to many of the key themes from earlier works of trans-boundary and transnational environmental history, but also introduces new issues and complications. Sharks are a prime example of mobile nature that crosses political and economic boundaries. Like most coastal countries, Australia and South Africa lay claim to territorial waters extending approximately $22 \mathrm{~km}$ offshore. They also possess Exclusive Economic Zones that range roughly $370 \mathrm{~km}$ from their coasts. Yet many species of sharks engage in migrations that far outstrip these territorial limits. Indeed, researchers recently tagged and tracked a white shark that made a nearly 20,000 km round-trip migration between Australia and South Africa. ${ }^{7}$ Interestingly, then, while these two nations have exchanged strategies for managing sharks for decades, they have only just realised that they have sometimes been dealing with the same fish. Shark mobility complicates national bather-safety policies that now demonstrably affect other such programs-as well as shark tourism and fishing industries - in international waters and those of distant countries. ${ }^{8}$

To this point, the history of shark control appears to fit neatly within the existing literature on mobile nature. But this topic also reveals new dimensions to transboundary environmental history, which structure the central theses of this paper. First, much of the existing literature on mobile nature addresses contiguous nations, land parcels or seas. The interconnected histories of shark management in Australia and South Africa present this theme on a much vaster geographic scale. This story highlights the need for environmental histories that transcend the Pacific and Indian Ocean worlds, while simultaneously maintaining attention to

6 Samuel Truett, 'Neighbors by Nature: Rethinking Region, Nation, and Environmental History in the U.S.-Mexico Borderlands', Environmental History 2, no. 2 (April 1997): 160-78, doi.org/10.2307/3985506; Kurkpatrick Dorsey, The Dawn of Conservation Diplomacy: U.S.-Canadian Wildlife Protection Treaties in the Progressive Era (Seattle, WA: University of Washington Press, 1998); Joseph E. Taylor III, Making Salmon: An Environmental History of the Northwest Fisheries Crisis (Seattle, WA: University of Washington Press, 1999), 11-12; Mark Fiege, 'The Weedy West: Mobile Nature, Boundaries, and Common Space in the Montana Landscape', The Western Historical Quarterly 36, no. 1 (Spring 2005): 123-43, doi.org/10.2307/25443100; Lissa Wadewitz, 'Pirates of the Salish Sea: Labor, Mobility, and Environment in the Transnational West', Pacific Historical Review 75, no. 4 (November 2006): 587-627, doi.org/10.1525/phr.2006.75.4.587; Joseph E. Taylor III, 'Boundary Terminology', Environmental History 13, no. 3 (July 2008): 454-81, doi.org/10.1093/envhis/13.3.454; Lissa K. Wadewitz, The Nature of Borders: Salmon, Boundaries, and Bandits on the Salish Sea (Vancouver: UBC Press, 2012), 6; Mary E. Mendoza, 'Unnatural Border: Race and Environment at the U.S.-Mexico Divide' (PhD diss., University of California, Davis, 2015), 2-12, 18-44.

7 Roger Highfield, 'Nicole the shark's record-breaking swim', The Telegraph , 7 October 2005. www.telegraph.co.uk/ news/worldnews/northamerica/usa/1500143/Nicole-the-sharks-record-breaking-swim.html, accessed 8 May 2015.

8 S. Tanaka et al., 'Age, growth, and genetic status of the white shark (Carcharodon carcharias) from Kashimanada, Japan', Marine and Freshwater Research 62, no. 6 (June 2011): 548, doi.org/10.1071/mf10130; C. A. Simpfendorfer et al., 'The importance of research and public opinion to conservation management of sharks and rays: a synthesis', Marine and Freshwater Research 62, no. 6 (June 2011): 522, doi.org/10.1071/mf11086. 
local contexts. ${ }^{9}$ Other marine environmental historians, including Kurkpatrick Dorsey and Carmel Finley, have examined transoceanic subjects. ${ }^{10}$ But whereas their research centres on efforts to conserve marine life, this paper describes an international conversation about how best to obstruct and eradicate nature. Second, most of the literature on trans-boundary environmental history has engaged with demarcations primarily intended to assert governance over, or claims of ownership against, people. Conversely, bather-safety programs generally emphasise the direct control of nature. They therefore provide a unique case study for exploring how efforts to control nature have historically intersected with attempts to discipline and regulate humans - a theme Mendoza has tackled from the opposite direction with her environmental history of the US-Mexico border. Third, with the possible exception of wolves, likely no group of animals has undergone a more radical shift in public sentiment across the course of the twentieth century than sharks. Once almost universally reviled as mindless killing machines, sharks now frequently elicit awe and admiration for their remarkable physical attributes and integral role in marine ecosystems. The history of shark management in Australia and South Africa thus demonstrates how changing perceptions of nature and the role of predators have forced policymakers to alter the placement and enforcement of barriers that structure interactions between the human and non-human worlds.

Although lying approximately $8,000 \mathrm{~km}$ apart, the coasts of South Africa and temperate Australia share similar mean annual sea surface temperatures. ${ }^{11}$ Their waters are thus home to many of the same marine organisms. These include species, like the southern bluefin tuna (Thunnus maccoyii), that the human inhabitants of both nations have celebrated as sources of food and livelihood. But these waters also share animals that have historically ranked among the most feared and loathed species on the planet-large sharks that occasionally kill people. Australian and South African waters are home to significant populations of the white shark (Carcharodon carcharias), the species that has likely contributed the most to fatal attacks on humans worldwide. Other large shark species that intermittently attack people, including the bronze whaler (Carcharhinus brachyurus), bull shark (Carcharhinus leucas), dusky shark (Carcharhinus obscurus) and tiger shark (Galeocerdo cuvier), also roam both these coasts. ${ }^{12}$

9 For important discussions of the Pacific Ocean World's environmental history, see J. R. McNeill, 'Of Rats and Men: A Synoptic Environmental History of the Island Pacific', Journal of World History 5, no. 2 (Fall 1994): 299-349; Ryan Tucker Jones, 'The Environment', in Pacific Histories: Ocean, Land, People, eds. David Armitage and Alison Bashford (London: Palgrave Macmillan, 2014), 121-42. For the Indian Ocean, see Vinita Damodaran, Anna Winterbottom and Alan Lester, eds., The East India Company and the Natural World (London: Palgrave Macmillan, 2014).

10 Carmel Finley, All the Fish in the Sea: Maximum Sustainable Yield and the Failure of Fisheries Management (Chicago, IL: University of Chicago Press, 2011); Kurkpatrick Dorsey, Whales and Nations: Environmental Diplomacy on the High Seas (Seattle, WA: University of Washington Press, 2013).

11 www.seatemperature.org/australia-pacific/australia/sydney.htm; www.seatemperature.org/africa/south-africa/ durban.htm, both accessed 20 January 2016.

12 John G. West, 'Changing Patterns of Shark Attacks in Australian Waters', Marine and Freshwater Research 62, no. 6 (June 2011): 745 , doi.org/10.1071/mf10181. 
The precise causes of unprovoked shark attacks remain subject to debate, but experts believe that most cases result from these giant fish mistaking people for natural prey. As other scholars have noted, in the vast majority of occasions when sharks encounter humans, the fish choose not to attack. Annual fatal shark encounters generally measure in single digits globally, and are statistically insignificant relative to deaths resulting from, for instance, automobile accidents or skin cancer. ${ }^{13}$ But fatalities from shark attacks receive disproportionate attention from the media and the public alike. These episodes can therefore substantially reduce beach visitation, damage tourism industries and erode public confidence in political leaders. For these reasons, policymakers in Australia and South Africa have long sought out means of reducing the likelihood of human-shark encounters in the waters under their jurisdiction. ${ }^{14}$

One of the world's earliest major attempts at shark management emerged in 1907 at the seaside town of Durban on South Africa's east coast. ${ }^{15}$ That year, city planners commissioned the construction of an imposing shark-proof barrier. In Durban, as elsewhere, human efforts to control the distribution and concentration of sharks arose in conjunction with the development of culturally specific understandings of beaches and their adjacent waters as places of relaxation and recreation. In the cases in Australia and South Africa, the model of the English seaside resort most powerfully shaped early European settlers' understandings of the beach. We can trace the antecedents of this ideal to mid-eighteenth-century England. At that time, the aristocracy began visiting the coast to benefit from the alleged salutary effect of swimming in and imbibing salt water. By the mid-nineteenth century, with advances in transportation infrastructure, middle- and working-class families were able to join in the holidaymaking. These new vacationers brought their own tastes, and within a few decades beaches came to be associated as much with entertainment as with convalescence. The aristocratic practice of nude bathing gave way to the conservative bathing attire favoured by the middle class. Meanwhile, 'mixed bathing'

13 George H. Burgess et al., 'Factors Contributing to Shark Attacks on Humans: A Volusia County, Florida, Case Study', in Sharks and Their Relatives II: Biodiversity, Adaptive Physiology, and Conservation, ed. Jeffrey C. Carrier et al. (New York: CRC Press, 2010), 541-46; West, 'Changing Patterns of Shark Attacks', 744-54; Jennifer Adams Martin, 'When Sharks Don't Attack: Wild Animal Agency in Historical Narratives', Environmental History 16 (July 2011): 451-55, doi.org/10.1093/envhis/emr051; A. Peter Klimley, Biology of Sharks and Rays (Chicago, IL: University of Chicago Press, 2013), 407-8.

14 Christopher Neff, 'Australian Beach Safety and the Politics of Shark Attacks', Coastal Management 40, no. 1 (January 2012): 88-106, doi.org/10.1080/08920753.2011.639867.

15 Lance van Sittert pioneered the field of South African marine environmental history; see for instance 'Making Like America: The Industrialization of the St. Helena Bay Fisheries, 1936-c.1956', Journal of Southern African Studies 19, no. 3 (September 1993): 422-46, doi.org/10.1080/03057079308708368; Lance van Sittert, “"The handmaiden of industry”: Marine science and fisheries development in South Africa 1895-1939', Studies in History and Philosophy of Science 26, no. 4 (December 1995): 531-58, doi.org/10.1016/0039-3681(95)00014-3. 
(females and males swimming together) yielded to gender-segregated swimming spaces. Emerging as the quintessential English beach town, East Sussex's Brighton became a favourite day trip for Londoners from all walks of life. ${ }^{16}$

Durban fell under British control in 1845 with the establishment of the colony of Natal. Recognising the region's abundant beaches and sunny weather, the city's English community soon set about re-creating the seaside resorts of their home country. They initially preferred to bathe in the confines of the harbour. But with immigrants boosting Durban's population in the late nineteenth century, city planners looked to the unsheltered Indian Ocean beaches to the east of town as potential sites of healthful recreation for fatigued urbanites. With the support of Natal's colonial legislature, the municipality invested heavily in infrastructure improvements. It dubbed the new development 'Ocean Beach'. By the early twentieth century, Durban was South Africa's most celebrated seaside destination. ${ }^{17}$ Reflecting their desire to re-create a British beach town, promoters described the city as 'the Brighton of South Africa'. ${ }^{18}$ Not surprisingly, such advertising primarily appealed to individuals of British descent. They made up the majority of tourists to the South African coast throughout the early twentieth century. ${ }^{19}$

Durban lay thousands of kilometres from England, however, and elements of South Africa's natural and human geography imperilled the city council's dreams of faithfully reproducing the English seaside. In particular, Durban's waters were home to bull, tiger and white sharks that occasionally attacked humans. And its streets and dwellings contained people of colour whom white South Africans believed had no business in their bathing facilities. Durban's planners responded by constructing a fenced-in enclosure that excluded perceived natural and human threats alike. Indeed, this structure was Ocean Beach's most ambitious piece of architecture, and the centrepiece of the council's seaside improvements. ${ }^{20}$

The Durban enclosure measured approximately $200 \mathrm{~m}$ in diameter, with a fence of steel piles and grids extending out into the ocean in a half-circle. ${ }^{21}$ In a striking feat of engineering, the city planners fenced off a large portion of the sea from

16 Leone Huntsman, Sand in Our Souls: The Beach in Australian History (Carlton South, Vic.: Melbourne University Press, 2001), 29-32; Douglas Booth, Australian Beach Cultures: The History of Sun, Sand, and Surf (London: Routledge, 2008), 23-4.

17 'Durban Beach Bill Improvement', Debates of the Legislative Assembly of the Colony of Natal: Third Session of the Fifth Parliament, Volume XLV, Comprising the Period from July 29 to August 31, 1908 (Pietermaritzburg: P. Davis and Sons, 1908), 274-5, 328-32.

18 Robert Preston-Whyte, 'Constructed Leisure Space: The Seaside at Durban', Annals of Tourism Research 28, no. 3 (2001): 584, doi.org/10.1016/s0160-7383(00)00067-0.

19 Heather Hughes, 'Struggling for a Day in the Sun: The Emergence of a Beach Culture among African People in Durban', in Art and Identity at Water's Edge, ed. Tricia Cusack (Farnham, Surrey: Ashgate, 2012), 141-46.

20 'Durban Beach Bill Improvement', 328-32.

21 'Durban Beach Bill Improvement', 274-5, 328-32; Natal Anti-Shark Measures Board (NASMB), Sharks: A Study on the Ocean's Supreme Predators and the Role of the Natal Anti-Shark Measures Board (Umhlanga Rocks, Natal: [The board], 1985), 8. 
sharks. Some contemporary observers considered this undertaking well worthwhile. 'The sharks round about the spot are so very numerous', wrote one commentator in 1914, 'that it was found necessary to erect a huge fence for the protection of bathers. ${ }^{22}$ Fear of sharks among people of European descent in the territory that became South Africa had deep historical roots. In 1852, HMS Birkenhead had famously sunk off Danger Point, $140 \mathrm{~km}$ from Capetown. Great white sharks allegedly killed so many of the British 'Tommys' (soldiers) trying to escape the vessel that the fish came to be called 'Tommy Haai' or 'Tommy Sharks' on the Cape south coast. ${ }^{23}$ Speaking more broadly, the psychological appeal of this and other shark barriers may have owed to the fact that beaches were inherently liminal spaces, existing at the edges of the terrestrial and marine worlds. The sense of unease that many people experienced upon entering an alien aquatic environment helps explain why the public perceived shark attacks with such dread. In the form of its steel grids, the Durban enclosure brought order to a chaotic space. This structure remained a local landmark for around 20 years, before the crowds outgrew it, and wave action and corrosion necessitated its demolition. ${ }^{24}$

Although a seemingly excessive response to the threat posed by shark attacks, this impenetrable barrier posed little harm to shark populations. By contrast, other local animal species that Durban's European inhabitants deemed unacceptably dangerous, including lions, leopards and crocodiles, found themselves hunted to local extinction by the 1860s. ${ }^{25}$ The more favourable outcome for sharks in this instance was hardly owed to positive perceptions of these fish. Indeed, many Europeans in this and other colonial settings applauded shark hunting, both for its alleged benefits to fisheries and human safety, and for the sport it offered, which was likened to big game hunting. ${ }^{26}$ In 1925 , a fisherman requested government subsidies for a South African shark fishery that would have the dual benefit of destroying supposedly dangerous creatures and providing marketable hides. The Department of Cape Fisheries declined the request, not because of environmental concerns, but due to a lack of funds. Indeed, they offered to assist the aspiring shark hunter by

22 Harold Baker, 'Joys of the Surf: The Fine Beach at Durban: Protected from Sharks', Evening News, 12 February $1914,6$.

23 Malcolm Turner, Shipwrecks and Salvage in South Africa (Cape Town: C. Struik, 1988), 72.

24 Sheldon F. J. Dudley and Geremy Cliff, 'Shark Control: Methods, Efficacy, and Ecological Impact', in Sharks and Their Relatives, ed. Carrier et al., 568. For the efforts of South African officials to use fencing to rationalise space on land, see Sean Archer, 'Technology and ecology in the Karoo: A century of windmills, wire and changing farming practice', Journal of South African Studies 26, no. 4 (December 2006): 112-38, doi.org/ 10.1080/03057070020008224.

25 Beverley Ellis, 'White settler impact on the environment of Durban, 1845-1870', in South Africa's Environmental History: Cases \& Comparisons, ed. Stephen Dovers, Ruth Edgecombe and Bill Guest (Athens, OH: Ohio University Press, 2003), 43-5.

26 Alfred Wilks Drayson, Sporting Scenes amongst the Kaffirs of South Africa (London: Cox and Wyman, 1860), 11-12; Alfred Wilks Drayson, 'Wild Fishing Among the Kroos: Off the Coast of Africa', Forest and Stream 1 (1873-74): 3; William E. Young, Shark! Shark!: The Thirty Year Odyssey of a Pioneer Shark Hunter (London: Hurst and Blackett, Ltd. [1933?]), 67-8. 
sharing information concerning stock locations. ${ }^{27}$ As we shall see, once policymakers identified cost-effective strategies for thinning shark numbers, they enthusiastically implemented them. Planners took steps to mitigate the environmental impacts of these methods only once perceptions of sharks became more favourable in the last quarter of the twentieth century.

Not all people could enjoy Ocean Beach's shark-free waters, however. White South Africans were adamant that people of colour not despoil this new Brighton. As historical photographs of the enclosure reveal, it included a barrier on land at least as formidable as that facing the sea (see Figure 1). Although we tend to associate racial segregation in South Africa with the apartheid regime that emerged in 1948, these policies actually have a deeper history. By the time of Ocean Beach's development in the early twentieth century, the European populations of South Africa had already implemented various forms of racial segregation. With the establishment of the Union of South Africa in 1910, legislators moved to formalise and standardise segregation policies: first in rural areas, with the Natives Land Act of 1913, and then in urban spaces, with the Natives (Urban Areas) Act of 1923. ${ }^{28}$

Beaches were sites of especially rigid segregation. South Africa's white colonial elites considered beach lounging and other acts of leisure to be marks of refinement, which demonstrated their superiority over non-whites. Conversely, if people of colour relaxed in this way, they supposedly exacerbated their inherent laziness. ${ }^{29}$ Hence, at Ocean Beach, and other white-patronised city beaches, non-whites could only enter when labouring for a white overseer. Durban's black population did eventually convince legislators to create a swimming space for them in 1929. But it was a segregated beach at a site with especially strong wave action, and it lacked basic facilities, adequate lifesaving and protection from sharks. In 1930, legislators passed Provincial Notice No. 206, which standardised and entrenched municipal beach segregation regulations. ${ }^{30}$

27 Louis P. Bowler to Person in Charge, Department of Cape Fisheries, 'Destruction of Sharks, Porpoises, and Dolphins', 12 November 1925. HEN 1497 180/1/3 Part 1, 1921-1930, 'Fishing Industry. Shark Fishing Industry. General', South African National Archives (SANA); Secretary, Board of Trade and Industry, to Captain Louis. P. Bowler, 'Destruction of Sharks, Porpoises and Dolphins-Application for Assistance', 14 December 1925. HEN 1497 180/1/3 Part 1, 1921-1930, 'Fishing Industry. Shark Fishing Industry. General', SANA.

28 Douglas Booth, The Race Game: Sport and Politics in South Africa (London: Frank Cass, 1998), 10-15, 19-26; Paul Maylam, South Africa's Racial Past: The history and historiography of racism, segregation and apartheid (Aldershot: Ashgate, 2001), 71-3, 115, 119, 143-50, 160, 172. For racial segregation at beaches in the US South, see Andrew W. Kahrl, The Land Was Ours: African American beaches from Jim Crow to the Sunbelt South (Cambridge, MA: Harvard University Press, 2012).

29 Hughes, 'Struggling for a Day in the Sun', 141, 146-7.

30 Preston-Whyte, 'Constructed Leisure Space', 584. 


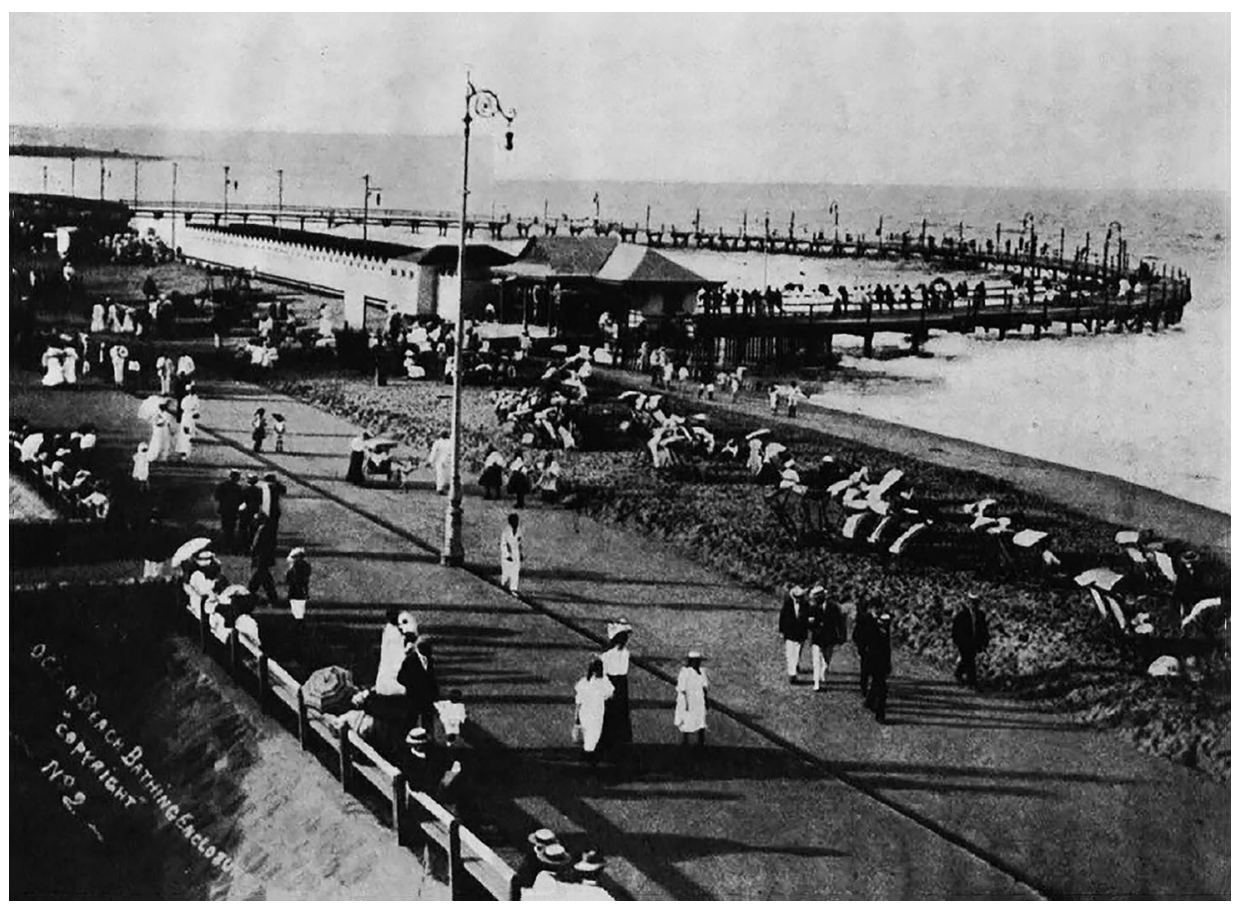

Figure 1: The Enclosure at Durban, 1907

Source: Shark Menace Advisory Committee, Report of the Shark Menace Advisory Committee on Suggested Methods of Protecting Bathers from Shark Attack (Sydney: Government Printer, 1935).

Besides acting on notions of civilised leisure, white South Africans also opposed non-white bathing at their beaches because of the exposure that accompanied it, even given the conservative swimming attire favoured in the early twentieth century. This would have been especially true at Ocean Beach, which permitted the contentious practice of 'mixed bathing'. As many scholars have argued, the body is a particularly potent site for the exertion of power and control. ${ }^{31}$ At beaches, power over the body included not only dictating what spaces an individual could enter, and in what attire, but also controlling which bodies were visible to whom. For South Africa's white men, the maintenance of power required preventing white women from viewing non-white males, or worse still, non-white men from seeing white women's bodies. Scholars have demonstrated that in South Africa, as elsewhere, white racism emerged in part over male fears of sex between white women and non-white men. ${ }^{32}$ Hinting that these psychosexual concerns shaped the pursuit of beach segregation, in 1933 magistrates sentenced an African youth with no prior convictions to six weeks in prison, with intermittent bouts of solitary confinement and limited rations. His sole crime was being 'insufficiently clothed' at a beach. ${ }^{33}$

31 Michel Foucault, Discipline and Punish: The Birth of the Prison (New York: Vintage Books, 1995).

32 Maylam, South Africa's Racial Past, 169-71.

33 Booth, The Race Game, 26. 
Bearing in mind this fixation with defending white female virtue, the claim of the Durban's city engineers that they constructed the Ocean Beach enclosure 'to ensure that there was safe bathing and as protection from shark attack' takes on potentially new meanings. ${ }^{34}$

Durban's famous shark fence may have arisen from genuine-if seemingly excessive-fears of attacks. But this attempt to impose a barrier against mobile nature also reflected and reinforced South African racial apprehensions. It is likely no coincidence that the first major attempt to fence off a protected bathing spot from wild and supposedly dangerous nature emerged in a country with a long history of trying to enclose safe white spaces from supposedly wild and dangerous black people. Indeed, by constructing a fence that marked off civilised territory from dangerous marine organisms and unaccompanied Africans, Durban's planners further entrenched the notion that black people were inherently primitive and savage, better suited to the unruly waves and shark-infested waters of their own segregated beach. ${ }^{35}$

Owing to their similar beaches and marine environments, and perhaps to a shared determination to bring order to a supposedly untamed land, Australian observers expressed admiration for the Durban enclosure. ${ }^{36}$ Australian travellers returning from Europe sometimes stopped at Durban, depending on the route they took. Following the completion of the barrier and other improvements, visitors came to perceive a trip to Ocean Beach as a requisite excursion. ${ }^{37}$ In 1914, one such Australian tourist recorded his impressions in a newspaper. He was struck by the parallels between Durban's waters and those of temperate Australia. 'The beach is precisely the same as our beaches in formation and colour', he noted. Unlike in Australia, though, Durbanites could proceed in perfect safety from sharks due to their enclosure. The writer concluded, 'Some of our seaside councils might ... learn a lot ... from a visit to this South African port'. ${ }^{38}$ Even at this early date, Australians

34 Engineers quoted by David H. Davies, Shark Attack and Its Relationship to Temperature, Beach Patronage and the Seasonal Abundance of Dangerous Sharks (Oceanographic Research Institute Investigational Report, no. 6) (Durban: Oceanographic Research Institute, 1963), 13-14 (emphasis added). Also see Booth, Australian Beach Cultures, 8.

35 For how racism and environmental inequality intersected in South Africa, see Nancy J. Jacobs, Environment, Power, and Injustice: A South African History (Cambridge: Cambridge University Press, 2003), 1. For how barriers against people and nature can reinforce perceptions of racial difference, see Mendoza, 'Unnatural Border', 3-4, 19-21; Miles Powell, Vanishing America: Species Extinction, Racial Peril, and the Origins of Conservation (Cambridge, MA: Harvard University Press, 2016). Also see Henri Lefebvre, The Production of Space (Malden, MA: Blackwell, 1998), 6, 10, 16; Preston-Whyte, 'Constructed Leisure Space', 583.

36 For parallels between Australian and South African environmental history, see Stephen Dovers, 'Commonalities and contrasts, pasts and presents: An Australian view', in Dovers, Edgecombe and Guest, South Africa's Environmental History, 227-39.

37 Hughes, 'Struggling for a Day in the Sun', 146.

38 Baker, 'Joys of the Surf', 6. 
were already looking to South Africa for solutions to the supposed shark menace facing both nations. In so doing, they revealed a shared marine environmental history linking the Indian and Pacific Ocean worlds. ${ }^{39}$

Like their South African counterparts, white Australians embraced the beach in the early twentieth century. This partly reflected a desire to re-create an English seaside resort in a new land. But it also owed to an emerging sense among Australians that exposure to sunlight and open waters had invigorating, even race-building effects. In 1907, W. Tongue and A. W. Relph wrote in the Sydney Morning Herald that 'surf-bathing is helping to build up a race of fine young hardy Australians, and everything should be done to encourage it'. ${ }^{40}$ Fit and ever vigilant-especially for signs of marauding sharks-lifesavers seemed to epitomise the beach's wholesome qualities. ${ }^{41}$ Unlike their South African counterparts, white Australians rarely had to compete with people of colour for access to these healthful shores. The combined assaults of disease, malnutrition and settler violence had devastated (but certainly not eliminated) the continent's Australian Aboriginal population. Then, beginning in 1901, the nation's 'White Australia' policy largely restricted immigration to individuals of European and especially British descent. Nonetheless, scholars have noted that, from the early twentieth century onward, Australia's iconic beach culture became closely connected to the nation's construction of whiteness. ${ }^{42}$

Lifesavers may have provided a sense of safety, but as in South Africa, Australian officials also initially responded to the perceived threat of shark attacks by attempting to fully fence off popular bathing sites. ${ }^{43}$ The town of Bunbury, Western Australia, toyed with the idea as early as 1900 . Proponents claimed that a large enclosure would allow the municipality to surpass rival beach towns. ${ }^{44}$ In the 1910s, boosters for Newcastle, New South Wales, made similar arguments in favour of a shark-proof

39 Australian and South African officials also looked to each other for strategies to manage race relations; see Jeremy Martens, 'A Transnational History of Immigration Restriction: Natal and New South Wales, 1896-97', Journal of Imperial and Commonwealth History 34, no. 3 (September 2006): 323-44, doi.org/10.1080/03086530600825969. 40 W. Tongue and A. W. Relph, 'Surf Bathing at Manly', Sydney Morning Herald, 7 November 1907, 6; also quoted in Huntsman, Sand in Our Souls, 70. For further claims of swimming's healthfulness, see E. Thompson, 'Swimming', The Port Augusta Dispatch, 18 December 1914, 3.

41 Huntsman, Sand in Our Souls, 68-71, 77-82.

42 For the desire to make Australia more 'English', see Thomas R. Dunlap, 'Australian Nature, European Culture: Anglo Settlers in Australia', Environmental History Review 17, no. 1 (Spring 1993): 26, doi.org/10.2307/3984889. For intersections of the 'White Australia' policy with environmental history, see Russell McGregor, 'Drawing the Local Colour Line: White Australia and the Tropical North', Journal of Pacific History 47, no. 3 (September 2012): 329-46, doi.org/10.1080/00223344.2012.692549; Sarah Irving, 'Governing Nature: The Problem of Northern Australia’, Australian Historical Studies 45, no. 3 (2014): 388-406, doi.org/10.1080/1031461x.2014.946521. Also see Booth, Australian Beach Cultures, 65; James Jupp, From White Australia to Woomera: The Story of Australian Immigration (Cambridge: Cambridge University Press, 2007), 8.

43 For Australia's best-known attempt to use fencing to manage mobile nature, the famous rabbit-proof fence, see Dunlap, 'Australian Nature, European Culture', 29.

44 John Duce, 'The Bathing Question: Correspondence to the Editor', Bunbury Herald, 6 November 1900, 3. 'Swimmer', 'Baths', Bunbury Herald, 12 November 1908, 3. 
fence. ${ }^{45}$ Well-meaning planners oversaw the construction of a shark barrier at Sirius Beach, near Sydney. But detractors noted that the design offered no protection to those who desired to bathe at low tide, when receding waters left the entire structure high and dry on the beach. ${ }^{46}$ Seeing an opportunity to enrich themselves while protecting the public, Australian amateur inventors filed dozens of patents for shark barriers in the 1920 s and 1930 s. $^{47}$

After discussing the issue for several years, in 1929 officials commissioned the construction of Australia's best-known shark-proof fence at Coogee Beach in the Sydney suburb of Randwick, which lies on the Pacific Ocean. From a pool of 300 submitted schemes, the city council chose a design involving a steel net that operators could raise or lower with a hoist, depending on weather conditions. When deployed, the barrier enclosed an approximately $200 \mathrm{~m}$ stretch of beach. ${ }^{48}$ A columnist for the Sydney Morning Herald deemed the fence a prudent investment, noting an increase in business at local hotels and other tourism-related enterprises. ${ }^{49}$ Other Sydney suburbs followed suit with shark fences of their own, though not on the scale of Coogee. ${ }^{50}$

In assessing whether to construct shark-proof enclosures at local beaches, Australian commentators often looked to Durban's example. In 1922, months before planners began discussing the possibility of a fence at Coogee, a writer for the Sydney Sportsman observed that 'At Durban it is possible to swim ... in safety and see on the other side of the netting, the sharks swimming to and fro, waiting vainly for

45 'Safety for Bathers', Newcastle Morning Herald and Miner's Advocate, 25 March 1918, 4; 'The Surf Calamity', Newcastle Morning Herald and Miners' Advocate, 20 January 1919, 3.

46 'Shark-Proof Fence Lets Sharks In', Evening News (Sydney), 24 October 1922, 1.

47 William Nicholls, 'Patent Application No. 9303/22: A Detachable shark proof net and means for securing same in position to protect bathers', 5 October 1922. AU1922009303BO, Australian National Archives (ANA); Henry Frank Bate and Henry Charles Bate, 'Patent Application No. 181/26: A shark proof bathing and surfing enclosure', 18 January 1926. AU1926000181BO, ANA; James Rutledge Louat, 'Application for Patent No. 17,870/29: Improvements in shark proof fences for ocean beaches', 15 January 1929. AU1929017870BO, ANA; Edward William Ward, 'Application for Patent No 20,186/29: An Improved Shark-proof Fence', 20 May 1929. AU1929020186BO, ANA; Albert John Feeney and George Phillips, 'Patent Application No. 26,443/30: An improved shark proof fence', 30 April 1930. AU1930026443BO, ANA; Francis Patrick Hart, Manager Industrial Machinery Company Limited, 'Application for Letters Patent for an invention by Industrial Machinery Company Limited, titled improvements in shark resisting nets for protection of swimming beaches', 3 January 1930. Item 4218190, ANA; William Walton Barrie, 'Application for Letters Patent for an invention by William Walton Barrie titled_-A Shark proof structure', 14 August 1929. Series A627, Control symbol 21894/1929, ANA; Arthur Ernest Whitelaw, 'Application for Letters Patent for an invention by Arthur Ernest Whitelaw, Titled-Improvements in means for constructing shark proof bathing enclosures', 2 November 1929. Series A627, 18275/1929, ANA; Frank O'Grady 'Application for Letters Patent for an invention by Frank O'Grady titled-Shark proof fence for ocean beaches', 30 January 1930. Series A627, 19376/1929, ANA.

48 'Shark Proof: Fence for Bathers at Coogee', World (Hobart, Tas.), 13 October 1922, 5; 'Shark-Proof Fence: For Coogee', Sydney Morning Herald, 17 July 1929, 18; 'Shark Menace: Shark Proof Fence for Coogee?', The Longreach Leader (Qld), 1 March 1929, 23; 'Coogee Shark Fence', Sydney Morning Herald, 14 Nov 1929, 17; 'Coogee Week: Shark-Proof Fence', Sydney Morning Herald, 19 November 1929, 12.

49 'Real Estate: Good Business: Coogee's Shark-proof Fence', Sydney Morning Herald, 18 December 1929, 10.

50 'Nielsen Park: Shark-proof Fence Installed', Sydney Morning Herald, 28 January 1930, 12. Also see Dudley and Cliff, 'Shark Control', 568. 
their prey'. The author ended with a challenge to the local authorities: 'They have effectively beaten the sharks at Durban — can we not beat them here?"51 In 1928, a year before the construction of Coogee's barrier, another Sydney suburb, BrightonLe-Sands, constructed a smaller enclosure 'on a plan of the bath at Durban'.52 In 1930, an author for the Sydney Sportsman complained of a hole in the Coogee fence, and deemed it 'strange' that 'this supposedly go-ahead city' could not properly protect its beach, while 'the comparatively backward city of Durban ... had a sharkproof enclosure [that] served its purpose admirably'..$^{53}$ Reflecting the insecurities of a nation that only achieved statehood in 1901, the writer considered sharkproof enclosures important symbols of progress and civilisation. But his allusion to Durban also spoke to a long-standing exchange between Australians and South Africans concerning how best to cope with potentially dangerous sharks. ${ }^{54}$

As in South Africa, Australian attempts to control nature intersected with efforts to administer people. Taking pride in their British heritage, many early-twentiethcentury Australians insisted on implementing middle-class Victorian morality at the seaside. Besides banning immodest swimwear, Australian municipalities also strove to prevent the practice of mixed bathing. As policymakers contemplated using fencing to block the entrance of sharks to popular swimming spots, they debated the impacts these structures would have on human behaviour. ${ }^{55}$

From an early date, Australian conversations over whether to construct shark-proof barriers, and in what form, became entangled with discussions of social propriety. Some commentators fretted that, by creating a single safe bathing zone, shark barriers would encourage mixed-gender bathing. In 1908, the council for the Melbourne suburb of St Kilda rejected a proposed shark-proof fence, for fear it would encourage men and women to swim together. ${ }^{56} \mathrm{~A}$ year later, referring to a different beach, a columnist advocated a barrier, precisely because the same fencing could be used to divide the enclosure into separate female and male zones, thereby eliminating the unseemly proceedings of mixed bathing ${ }^{5}{ }^{57}$ In early twentieth-century Australia, discussions of shark management melded with attempts to impose morality by creating gendered spaces, a process reflected in contemporaneous efforts to restrict women to the domestic sphere. ${ }^{58}$

\footnotetext{
51 'Shark-Proof Fence', Newcastle Sun, 4 March 1922, 3; 'What They Do in Durban', Sydney Sportsman, 7 March 1922, 1.

52 'St. Kilda Bath Proposals', The Prahran Telegraph (Vic.), 5 January 1923, 8.

53 'Ware Shark', Sydney Sportsman, 14 January 1930, 8.

54 Also see 'Example of Durban', The Mercury (Hobart, Tas.), 15 January 1929, 6; 'New Shark Proof Baths to be Opened Today', Evening News (Sydney), 15 September 1928, 1.

55 'Mixed Bathing', Record (Emerald Hill, Vic.), 28 September 1912, 2; 'No Mixed Bathing: Council Ban at St. Kilda: Opposition of Women', Barrier Miner (Broken Hill, NSW), 9 October 1933, 3. Also see Huntsman, Sand in Our Souls, 59-61; Booth, Australian Beach Cultures, 22-3, 32-3.

56 'A Novel Suggestion: Shark-Proof Fencing for St. Kilda Bathers', The Prahran Telegraph, 15 February 1908, 5.

57 Richard B. Armstrong, 'South Beach, Fremantle', The West Australian, 18 February 1909, 6.

58 Also see 'Round about Geraldton', Sunday Times, 1 March 1914, 4 S.
} 
As other scholars have noted, Australia's history as a penal settlement instilled in many of its elites a particular aversion to social disorder. We can see this reflected in discussions of shark barriers, with commentators often explicitly connecting the exclusion of natural threats to the elimination of human ones. Although St Kilda's council rejected the proposed barrier in 1908, a local pundit did note that 'some safeguard to bathers against sharks seems to be really needed ... especially landsharks, who $\ldots$ have been depredating among the watches and chains of bathers'. ${ }^{59}$ In 1930 similar allusions to criminal 'land-sharks' emerged in debates over whether Brisbane's city planners should construct an enclosure at a nearby beach. ${ }^{60}$

Numerous commentators also directly compared the disorderly fraternisation of mixed bathing to the perilous mingling of humans and sharks in the water. In 1912, a columnist stated: 'I am not in favour of mixed bathing at any price, because I think things are mixed quite enough in this world - in fact, too much for my liking.' She compared this transgression to sharks moving onto dry land. ${ }^{61}$ Seven years later, another observer exclaimed that ' $[\mathrm{t}]$ he very much mixed bathing in these seaside waters were too much mixed for my liking', with 'Alligators, sharks, stingrays, devilfish, [and] sea-snakes' joining the human swimmers. ${ }^{62}$ In 1934, an onlooker made a similar comparison, noting of a recent visit to the beach that in addition to the women present, 'two playful sharks provided very mixed bathing' ${ }^{63}$ Given that 'mixed bathing' was accepted practice by this time, this final commentator may have intended to poke fun at an outdated moral code. Yet, at least in the first two instances, desires for an ordered social and natural landscape merged in debates over shark management.

Shark-proof barriers took far less of a toll on shark populations than would later meshing and baited-hook programs. But as in South Africa, this outcome owed more to technological and financial limitations than environmental concerns. When sharks did inadvertently enter the fenced-in enclosures and become trapped, locals quickly killed them, even if the crowd identified the offending fish as a harmless species. ${ }^{64} \mathrm{We}$ can probably better ascertain the prevailing attitude among early-twentieth-century Australians towards predators by considering the case of the thylacine, or 'Tasmanian tiger'. A unique species with a head like a wolf, a striped body and a marsupial pouch, the thylacine found itself hunted to extinction in the

59 Simple Simon, 'Seen and Heard', The Prahran Telegraph, 15 February 1908, 5.

60 'Shark Proof Fence', The Western Champion (Barcaldine, Qld), 28 June 1930, 4. Also see Huntsman, Sand in Our Souls, 66.

61 'Mixed Bathing', The South Eastern Times (Millicent, SA), 22 March 1912, 2.

62 'A Christmas Day in the North', Sunday Times (Sydney), 21 December 1919, 22.

63 'Very Mixed Bathing at Burleigh', The Telegraph (Brisbane), 23 April 1934, 8.

64 'Dispatching a Shark', The Brisbane Courier, 23 November 1920. 
1930s, with government officials providing bounties to encourage the slaughter. Australian legislators offered similar bounties for dingos, pelicans, eagles and any other predator deemed to pose a risk to commercially valuable livestock or fisheries. ${ }^{65}$

As some prescient observers had forewarned, Australians could never hope to enclose every popular swimming spot on a continent. ${ }^{66}$ This was partly a consequence of scale, but it also reflected the agency of the ocean, the raging waves and powerful currents of which quickly made scrap metal of most fences. Shark attacks thus remained a real, if statistically improbable, possibility for swimmers. New South Wales endured 13 attacks, seven of which were fatal, between 1918 and 1929. In response, the state government established a Shark Menace Committee to weigh potential options. The committee reported that, for most beaches, shark-proof fences were not a viable long-term option, because wave action would destroy them. This left the possibility of humans avoiding waters where sharks were likely to be present — which the committee recommended, but feared would be unpopular—or finding a way to eliminate or substantially reduce shark populations. After ruling out bombs and electrical repellents, the group determined that 'regular and systematic netting affords a cheap and effective way of greatly minimizing the shark peril'. Decreasing shark numbers would make it less likely for humans to encounter them, the committee reasoned. Moreover, the surviving sharks would have proportionately more natural prey available to them, reducing their motivation to consume people. ${ }^{67}$

These recommendations do not appear to have led to policy changes. But after four more attacks claimed two human lives in New South Wales's waters in the early 1930s, the Surf Life Saving Association convinced the state government to commission a second Shark Menace Advisory Committee in 1934. As with its predecessor, the group stressed that enclosures were impractical. Coogee represented a rare exception due to its unique geography. The committee thus confirmed the findings of the earlier body by stressing the importance of safe bathing practices, while also recommending a systematic meshing program. The group opted for meshing after hearing testimony from pioneer commercial shark fishermen. In an omen of future developments in global shark fisheries, they had observed that shark numbers rapidly diminished in the face of sustained harvests. ${ }^{68}$

65 Dunlap, 'Australian Nature, European Culture', 32-3.

66 'Example of Durban', 6.

67 New South Wales Shark Menace Committee, General Report of Sub-Committee (Sydney: Government Printer, 1929), 1-4 (National Library of Australia: Np 363.14 S955); also quoted in Dudley and Cliff, 'Shark Control', 572. Some municipalities also requested government-funded air patrols for sharks; see 'Request for a/c Aircraft shark patrols', 9 January 1928. Series A705, control symbol 9/1/1928, ANA; [No. 23 Fighter Squadron] 'Search and Rescue-Shark Patrol', 15 December 1952. Series A11250, control symbol 21/8/AIR PART 1, ANA.

68 Shark Menace Advisory Committee, Report of the Shark Menace Advisory Committee on Suggested Methods of Protecting Bathers from Shark Attack (Sydney: Government Printer, 1935), 8-11, 27, 32, 40-1. For observations of commercial shark fishermen, see Norman Caldwell and Norman Ellison, Fangs of the Sea (Sydney: Angus and Robertson, 1936), 22. Also see 'Anti-Shark Protection', The Daily News (Perth, WA), 17 September 1935, 4; Neff, 'Australian Beach Safety', 90. 
In 1937 the New South Wales Shark Meshing Program commenced with the installation of a series of anchored gill nets off Sydney's beaches from Palm Beach to Cronulla. Policymakers hoped to reduce shark populations, rather than create a complete barrier. Thus, operators left openings between nets, removed them each day before redeploying them at night and cycled locations, leaving each beach unprotected for a few nights per month. In their first 17 months of operation, the nets snared 1,500 sharks. Suggesting a population decrease, the program caught 473 sharks over the following two-year period. With the exception of a brief hiatus during the Second World War, the meshing program at Sydney beaches has continued through to the present. In 1949 New South Wales expanded the program to Wollongong and Newcastle. In 1962 Queensland followed suit with a meshing and drum-line program that eventually provided some form of protection to all surf club-patrolled beaches along 2,400 $\mathrm{km}$ of coastline. A drastic reduction in attack rates ensued. ${ }^{69}$

South African officials adopted this Australian innovation, revealing how the exchange of shark management strategies between Australia and South Africa contributed to a transoceanic environmental history. South Africa experienced few fatal shark attacks in the early twentieth century, perhaps contributing to the decision of Durban city planners to dismantle their enclosure. With beach crowds continuing to swell, however, the 1940s saw a major rise in fatal shark bites. By 1948, Durban officials were contemplating rebuilding their fence, but they baulked at the estimated cost. South African researchers investigated numerous methods, including barriers of bubbles or sound waves, and even depth charges. Then, in 1951, The Surf Life Saving Association of South Africa encountered an article from the Medical Journal of Australia highlighting the immense success of the New South Wales meshing program. The following year, Durban Corporation established nets off its beaches. Fatal attacks immediately ceased there for the next several decades. ${ }^{70}$ New South Wales's Pacific Ocean innovation had found its way to Durban's Indian Ocean waters. Yet 14 years passed before this transfer took place. This delay reveals that connections between Australia's and South Africa's shark management programs waxed and waned depending on natural variability (especially surrounding attack rates) and how outward-looking the relevant institutional bodies were at any given time.

69 Geremy Cliff and Sheldon F. Dudley, 'Reducing the Environmental Impact of Shark-Control Programs: A Case Study from KwaZulu-Natal, South Africa', Marine and Freshwater Research 62, no. 6 (June 2011), 700, doi.org/10.1071/mf10182; T. S. Wallett, 'Analysis of Shark Meshing Returns off the Natal Coast' (MA diss., University of Natal, Durban, 1973), 3. Some found it wasteful not to utilise the sharks captured in these meshing programs; see Technical Research Section, Fisheries Division, Department of Primary Industry, Utilisation of Sharks (Canberra: [The department], 1961) (University of Adelaide Library: TT6356-6360). Also see Ben Daley, The Great Barrier Reef: An Environmental History (London: Routledge, 2014), 119.

70 NASMB, Sharks, 5, 8, 9; Wallett, 'Analysis of Shark Meshing Returns', 4. 
Neighbouring beaches that lacked Durban's new defences, though, remained vulnerable. During the summer of 1957-58, the nation's east coast endured an unusual escalation in attacks, five of which proved fatal. Dubbed 'Black December', for the month during which the attacks commenced, this string of encounters panicked would-be bathers. This produced severe economic hardship for the region's tourism-dependent beach towns. ${ }^{71}$ Rather than assuaging these fears, prominent South African marine researchers within the National Physical Research Laboratory of the Council for Scientific and Industrial Research (NPRL) fanned the hysteria. They suggested that only heavy investment in their projects could solve the crisis. A genuine desire to increase public safety no doubt motivated this scientific community. But the contrast between their research publications-which downplayed the risk of attacks — and a sensationalist pamphlet requesting donations from the public — which warned of the 'grave danger of shark attacks' — suggested financial incentives were also at play. ${ }^{72}$

Over the next few years, officials explored a number of strategies to improve bather safety. In 1958, NPRL researchers began experimenting with electrical repellents, but they proved impractical. Beach communities also erected a variety of physical barriers, but none were able to withstand the powerful surf. ${ }^{73}$ South Africa's Governor General, Charles Robberts Swart, commissioned a destroyer to explode depth charges up and down the Natal coast, before accepting the absurdity of this strategy. ${ }^{74}$ An amputee shark attack survivor named John E. Hughes repeatedly requested government sponsorship for a long-distance walk to raise funds to eliminate the shark 'menace'. Despite his assurance that he only required 'a car to take me to Maritzburg and follow me to Durban, carrying my spare leg, food and water and to afford me protection from dogs, snakes, monkeys, hoboes, and stray natives', the Governor General's office seemed reluctant to associate themselves with him. ${ }^{75}$ As news spread of Durban's success, though, the meshing strategy imported from Australia became the preferred method. Multiple municipalities had adopted similar programs by the early 1960s. In 1964, Natal's government formed the Natal Anti-Shark Measures Board (NASMB) to oversee bather-safety programs in the

71 Wallett, 'Analysis of Shark Meshing Returns', 4; NASMB, Sharks, 5; Dudley and Cliff, 'Shark Control', 566-8.

72 For an assertion of the relative insignificance of shark attacks, see Davies, Shark Attack, 1. For an inflammatory pamphlet, see Anti-Shark Action Committee, 'It Began With This ...' (1961?), 7. SPT 46, SANA. The researchers also petitioned the government for funds to conduct 'general research' to thwart the 'shark menace'; see J. D. Roberts, Chairman, Anti-Shark Action Committee, to Governor General C. R. Swart, 24 February 1961. SPT 46, SANA; David H. Davies, Director, Research Professor, University of Natal, to C. R. Swart, 23 February 1961. SPT 46, SANA.

73 J. P. A. Lochner, 'Memorandum on Anti-Shark Investigations in South Africa' (National Physical Research Laboratory, Council for Scientific and Industrial Research, 1961?). SPT 46, SANA; NASMB, 'Annual Report for the year ended 31st Dec., 1964' (Natal: [The board], 1965) (National Library of South Africa (NLSA): P 4940 W00404 1964).

74 C. R. Swart, Governor General, to Mr. J. D. Roberts, 28 February 1961. SPT 46, SANA.

75 John E. Hughes to C. R. Swart, 'Shark Menace', 11 February 1962, 3. SPT 46, SANA. 
province. Initially, the board coordinated net deployments conducted by municipal workers or private contractors. But between 1974 and 1982, the organisation gradually assumed direct control over all operations. ${ }^{76}$

The NASMB attempted to order the natural world to minimise the possibility of human-shark encounters. In contrast to the earlier enclosure at Durban, which fully fenced off a portion of the sea, this meshing system-like its Australian counterpartoperated by reducing shark numbers in popular bathing areas. Operators deployed nets parallel to shore at a depth of 10 to $14 \mathrm{~m}$, and a distance from land of 300 to $500 \mathrm{~m} .{ }^{77}$ In some instances, the crews also set drum lines adjacent to the nets. Operators inspected the nets and drum lines every few days. Reflecting prevailing perceptions of sharks as dangerous to humans and destructive to commercial fish stocks, crews initially killed all captured large sharks. The board also experimented with a complementary long-line fishery, before concluding that it removed too few sharks to justify its costs. These strategies allowed Natal's bather-safety programs to destroy 1,404 sharks in $1965 .{ }^{78}$ By 1970 , that number had dropped to 744 and, the following year, the NASMB confidently announced that shark populations in the region were in a state of 'continued decline'. At this point, few researchers saw this decrease as a cause for concern. ${ }^{79}$

The NASMB sought to control more than just sharks, for in apartheid South Africa such a program also required the channelling of human beings into spaces and roles that officials deemed appropriate. In its promotional materials, the board boasted not only of managing shark populations, but also of disciplining black crews. A 1984 publication celebrating the NASMB's first 20 years included a photograph depicting African men performing synchronised exercises at the behest of a white officer. The accompanying caption read: 'Discipline has always been the foundation of the Board's efficiency' (see Figure 2). ${ }^{80}$ For the NASMB, the effective control of shark populations was inseparable from the careful administration of black crew members. In 1970, the board constructed a headquarters in Durban, complete with its own segregated 'black crew compound'. ${ }^{81}$ Each black crew followed the commands of white Shark Control Officers, and the NASMB offered annual prizes

76 NASMB, 'Annual Report for the year ended 31st Dec., 1974' (Natal: [The board], 1975), 3 (NLSA: P 4940 W00404 1974); 'Annual Report for the year ended 31st Dec., 1982' (Natal: [The board], 1983), 2 (NLSA: P 4940 W00404 1982). Also see Wallett, 'Analysis of Shark Meshing Returns', 1, 4; NASMB, Sharks, 1, 9; Dudley and Cliff, 'Shark Control', 568-70; Cliff and Dudley, 'Reducing the Environmental Impact', 701-2.

77 Cliff and Dudley, 'Reducing the Environmental Impact', 701.

78 NASMB, 'Annual Report for the year ended 31st Dec., 1965' (Natal: [The board], 1966) (NLSA: P 4940 W00404 1966).

79 NASMB, 'Annual Report for the year ended 31st Dec., 1970' (Natal: [The board], 1971), 3 (NLSA: P 4940 W00404 1970); NASMB, 'Annual Report for the year ended 31st Dec., 1971' (Natal: [The board], 1972), 3 (NLSA: P 4940 W00404 1971); NASMB, Sharks, 7, 9.

80 NASMB, Sharks, 3, 4.

81 NASMB, 'Annual Report for the year ended 31st Dec., 1972', 3 (Natal: [The board], 1973) (NLSA: P 4940 W00404 1972). 
to the most well-ordered team. ${ }^{82}$ Natal stubbornly refused to relinquish control over its marine fisheries to the national state, and so these programs partly reflected resilient provincial traditions of colonial science and native administration. But these procedures also fitted well with the prevailing apartheid national regime, which commenced in 1948, and included brutal political repression of black people and systematic segregation, including of public spaces. ${ }^{83}$ Since the collapse of Apartheid in 1994 , the Board has adopted far more progressive labour practices.

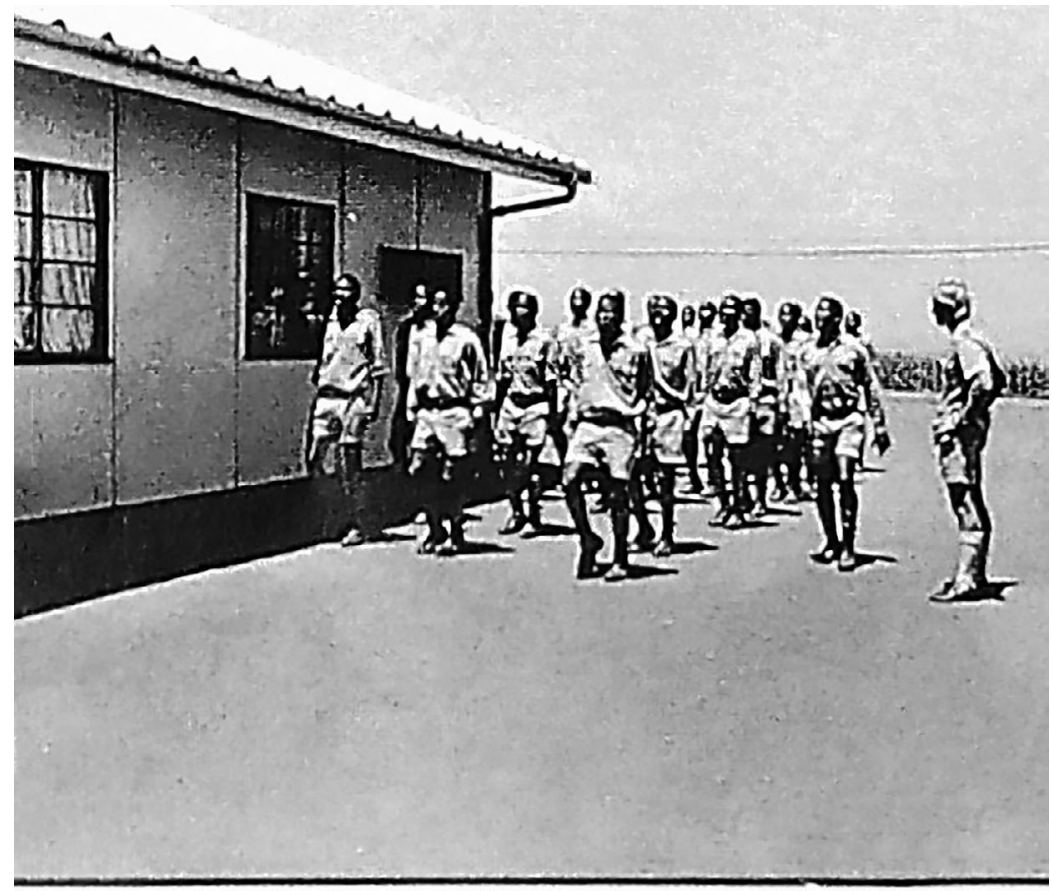

\section{Discipline has always been the foundation of the Board's efficiency}

Figure 2: Image from promotional material for the Natal Anti-Shark Measures Board, 1984

Source: NASMB, Sharks, 3.

Besides instilling discipline in black crews, the NASMB could claim to be bringing greater safety to an activity that exploded in popularity among Australians and South Africans beginning in the 1960s: surfing. Pacific Islanders invented surfing and helped popularise the sport through the influence of iconic pioneers. These included Vanuatu's Tommy Tanna (who primarily bodysurfed) and Hawaii's Duke

82 NASMB, 'Annual Report for the year ended 31st Dec., 1978' (Natal: [The board], 1979), 4 (NLSA: P 4940 W00404 1978).

83 Maylam, South Africa's Racial Past, 179-81. 
Kahanamoku (who actually rode a board) in the late nineteenth and early twentieth centuries, respectively. ${ }^{84}$ But modern surf culture emerged in California in the 1950s. There, a group of beachgoers took advantage of post-war affluence and leisure time - along with new, lighter board designs - to develop a style of riding that combined skill and self-expression. Through the influence of Hollywood films, popular surf magazines and globetrotting American surfers, this culture rapidly diffused to Australia and South Africa. ${ }^{85}$

Surfers are notoriously territorial, and their efforts to defend their claims to the best waves inevitably brought them into conflict with other beach users. In Australia in the 1960s, this often led to clashes between conservative surf lifesavers and bohemian surfers. ${ }^{86}$ In South Africa, where the dominant culture claimed surfing as a 'white' sport, it led to increasing efforts at beach apartheid. This occurred through official and unofficial means. In 1960, in an effort to uphold the segregation of bathers and surfers, South Africa's legislators amended the 1953 Reservation of Separate Amenities Act. They clarified that, in the wording of the legislation, 'land' actually extended $4.8 \mathrm{~km}$ out to sea. ${ }^{87}$ Meanwhile, as white surfers came to understand their sport as an extension of their racial identity, they used physical intimidation to block people of colour from popular surfing spots. The strong association between surfing and whiteness meant that when Durban assumed the title of 'Surf City' in the mid-1960s, it reinforced the racial exclusivity of its main beaches. In a tragic irony, the black crews of the NASMB thus diligently ensured the safety of waters that were often off limits to them. Black South African surfers certainly existed, but they generally had to hone their craft at segregated beaches, which received lesser government expenditures for safety. By the 1980s, though, with many South Africans aggressively demanding an end to apartheid, black surfers such as Ahmed Collier challenged beach segregation laws, even in the face of repeated arrests. In 1989, the government relented and desegregated beaches-five years before the nation's first open elections officially brought apartheid to a close. ${ }^{88}$

By the early 1970s, meshing and drum-line programs in Australia and South Africa had produced substantial declines in per capita bather fatalities resulting from shark attacks. In fact, recent research suggests that these programs have reduced the frequency of attacks at protected beaches by approximately 90 per cent. Yet, just as officials in these two nations seemed to have achieved a permanent solution to the 'shark menace', they encountered a new challenge: people were beginning to see sharks in a more favourable light, and were becoming far less comfortable

84 Huntsman, Sand in Our Souls, 97; Booth, Australian Beach Cultures, 36-9, 87-95.

85 Glen Thompson, 'Reimagining Surf City: surfing and the making of the post-apartheid beach in South Africa',

International Journal of the History of Sport 28, no. 15 (2011): 2119, doi.org/10.1080/09523367.2011.622111.

86 Huntsman, Sand in Our Souls, 98, 100-3; Booth, Australian Beach Cultures, 6, 11.

87 Booth, The Race Game, 58, 76-7.

88 Thompson, 'Reimagining Surf City', 2115-19, 2120-3. 
with programs that pursued these majestic creatures' destruction. As a consequence of these changing perceptions of sharks, and of the environment more broadly, policymakers had to rethink the placement and enforcement of boundaries structuring interactions between humans and mobile nature. ${ }^{89}$

In the last quarter of the twentieth century, the English-speaking world underwent a radical transformation in perceptions of large sharks. This was especially true with regard to the species responsible for the majority of global fatal attacks - the white shark. Once seen as primitive killing machines that devastated commercially valuable fish stocks and maimed or killed bathers at every opportunity, large sharks came to be celebrated as regionally iconic species that demonstrated nature's splendour and the interdependence of all life on the planet. Although many scholars have noted this sea change in attitudes (with some wishing it would proceed further), it has proven difficult to systematically demonstrate. A few years ago, a team of researchers found a solution. Through content analysis of the 53-year run of the popular Australian magazine Sportdiving, they revealed a marked shift in discussions of sharks. Prior to 1975, contributors to the magazine expressed fear or annoyance at the presence of sharks, and recorded their desire to destroy them through spear fishing. By the mid-1980s, though, writers described shark encounters as sources of excitement and wonderment, and emphasised the need to respect these imposing creatures when entering their realm. ${ }^{90}$

Several factors accounted for this transition. Steven Spielberg's summer blockbuster Jaws appeared in 1975, featuring a gigantic white shark as its villain. This film heightened public fears of sharks. It also likely led to a temporary escalation in informal attempts to eradicate white sharks through sport hunting and other methods. But, as the small community of shark conservationists that existed at the time noted, the film also generated immense popular interest in sharks, and thereby indirectly contributed to an increase in efforts to research and preserve the white shark and other species. More recent film depictions of sharks, such as the Discovery Channel's popular Air Jaws series, depicting breaching great whites in South Africa's False Bay, have had a similarly double-edged impact. ${ }^{91}$

Shark-related ecotourism also contributed to this shift. Pioneered in the mid1960s by an Australian shark attack survivor named Rodney Fox, shark-cage diving grew in popularity in Australia and South Africa through the last quarter of the twentieth century. Fox and other tour operators pushed for legislators to protect the white shark in particular, which they had come to admire, and that now provided

\footnotetext{
89 For estimated reductions in attacks, see Dudley and Cliff, 'Shark Control', 573.

90 Sally Whatmough et al., 'From hunters to nature observers: A record of 53 years of diver attitudes towards sharks and rays and marine protected areas', Marine and Freshwater Research 62, no. 6 (2011), 755-8. For a personal account of such a transition in attitudes, see Theo Ferreira, Shark Man: My Obsession with the Great White Shark (Cape Town: Sunbird, 2007).

91 Rodney Fox, Sharks, the Sea, and Me (Mile End, South Australia: Wakefield, 2013), 94.
} 
a significant source of tourism revenue for coastal communities. Yet critics have noted that the 'chumming' (baiting with animal parts) carried out by some tour operators may have encouraged sharks to associate humans with food, encouraging attacks and fuelling retaliatory culls. ${ }^{92}$

Perhaps most important, beginning in the 1960s and gaining momentum thereafter, environmentalists powerfully shaped public perceptions of nature by making arguments for the ecological interdependence of all organisms, including sharks and other predators. In the late twentieth century, the listing of some large shark species as endangered (Australia listed the great white in 1999) reflected, and likely contributed to, a mounting perception of sharks as vulnerable, rather than threatening. ${ }^{93}$

These changing views forced policymakers to alter their bather-protection strategies to minimise unnecessary harm to shark populations. In Natal, where one administrative body came to oversee all shark management activities, the record is particularly clear. In 1975, the NASMB began removing netting during the annual sardine run to prevent excessive numbers of sharks from becoming ensnared. At the time, officials saw this change as a means of minimising damage to the nets, but in ensuing years, the board emphasised the policy's ecological benefits. ${ }^{94}$ In a further effort to cultivate a more environmentally friendly image, the Natal Anti-Shark Measures Board dropped 'Anti' from its name in 1985. Initially, the board killed all large sharks found alive, but this policy gradually transformed with the release of species deemed to pose little threat. By 1989 crews were releasing all live sharks, even white sharks and tiger sharks. Natal's netting peaked at a length of $45 \mathrm{~km}$ in 1992, but between 1999 and 2005 the board cut this back to $27 \mathrm{~km}$. Today, the Natal Shark Board is one of the world's leading institutes for the scientific study of sharks. Researchers estimate that these combined changes have contributed to a 64 per cent reduction in board-caused shark mortality since the 1980s. ${ }^{95}$

92 For the development of shark tourism, see Valerie Taylor, 'The Day I Met Mr. Big Alone in the Cage, without Air, and the Exit to Safety', Australian Women's Weekly, 6 May 1970, 24; Fox, Sharks, the Sea, and Me, 54-8; Klimley, Biology of Sharks and Rays, 424. For the efforts of Fox and other tour operators to secure protection for white sharks, see personal papers of Rodney Fox: Rodney Fox to R. A. Stevens (Director of Fisheries, South Australia), 28 July 1986; R. A. Stevens to Rodney Fox, 7 Aug 1986; Marty Snyderman (Ocean Environment, Motion Picture and Still Photography, San Diego, CA) to Rodney Fox, 2 March 1987; Neil Wells (World Society for the Protection of Animals) to Rodney Fox, 16 March 1987; Howard Hall (SummerHall Films, San Diego, CA) to Rodney Fox, 19 March 1987; Marty Snyderman to R. A. Stevens, 19 March 1987; Carl Roessler, See and Sea Travel, Inc, San Francisco, to R. A. Stevens (?), 20 March 1987; Rodney Fox to Dr Leonard Compagno (Shark Research Center, Cape Town, South Africa), 16 January 1995. (Papers in possession of Rodney Fox.)

93 Simpfendorfer et al., 'The importance of research and public opinion to conservation management of sharks and rays', 518-27.

94 NASMB, 'Annual Report for the year ended 31st Dec., 1975' (Natal: [The board], 1976), 6 (NLSA: P 4940 W00404 1975); NASMB, Sharks, 7.

95 Cliff and Dudley, 'Reducing the Environmental Impact', 702-7. 
Australian and South African shark management still produced diminutions in shark populations, though. Despite efforts to minimise unnecessary loss of life, meshing and drum-line programs still operated on the premise that reducing numbers of sharks near beaches lessened the likelihood of human-shark encounters. This objective necessarily entailed the destruction of numerous sharks. Even in South Africa, which eventually adopted a zero-kill policy, many sharks perished before crews arrived, and others surely failed to survive after being disentangled from gill nets or cut free from drum lines. Ironically, meshing programs provide the best evidence for downward population trends among some large shark species. Having set nets in fixed locations year after year, and compiled careful catch logs, these programs produced useful records of the marine organisms present in select Australian and South African waters from the 1970s-and in some places even earlier-through the present. ${ }^{96}$

These logs indicate substantial declines in the catch per unit effort (the number or tonnage of individuals caught for each measure of net or hooks in the water) of several, although not all, of the target species. In New South Wales, between 1950 and 2010, catch rates for white sharks and tiger sharks, as well as some less dangerous species, declined. Moreover, in the case of white and tiger sharks, smaller individuals made up an increasing proportion of the population, a telltale sign of dwindling stocks. ${ }^{97}$ Between 1978 and 2003, in the area that became KwaZuluNatal (a South African province created in 1994 by merging the Zulu homeland with Natal province), catch statistics for the bull shark and three other less-dreaded species waned. Unfortunately, these records cannot tell us whether these reductions resulted from bather-safety programs, or from escalating commercial fisheries, which often took a much larger, if less geographically focused, catch. Yet, in at least some cases, such as that of the bull shark in KwaZulu-Natal, researchers think the meshing programs played a primary role. ${ }^{98}$

\footnotetext{
96 Wallett, 'Analysis of Shark Meshing Returns', 1; D. D. Reid et al., 'Decadal trends in shark catches and effort from the New South Wales, Australia, Shark Meshing Program, 1950-2010', Marine and Freshwater Research 62, no. 6 (June 2011): 676 .

97 Reid et al., 'Decadal trends', 676, 688; R. S. K. Barnes and R. N. Hughes, eds., An Introduction to Marine Ecology, 3rd ed. (Oxford: Blackwell, 2004), 157.

98 Dudley and Cliff, 'Shark Control', 573, 576. For historical commercial shark fisheries in Australia, see T. C. Roughley, 'Catching Sharks for Profit', The Australian Museum Magazine 3, no. 5 (January-March 1928): 149-55; 'Shark fisheries', Series A461, control symbol F345/1/2 (1933-1939), ANA; Caldwell and Ellison, Fangs of the Sea; Eric J. Harrison, 'Export of shark or fish livers-Cam and Sons Pty Ltd', 22 March, 1941, Series A1539, control symbol 1941/W/3344, ANA; 'Fish-Shark', Series A9692, control symbol D/7 (March 1941-September 1942), ANA; E. R. Yarham, 'The Shark Becomes an Ally', Sydney Morning Herald, April 28 1945; 'Shark Livers—prices and general', 15 March 1948, Series 376/6, control symbol P1947/7477, ANA; R. R. Ellen, Australian Government Trade Commissioner, The Market for Shark Hides in the United States (Canberra: Department of Commerce and Agriculture, 1950); Fisheries and Game Department, Victoria, 'General Circular No. 3: Management of Edible Shark Fishery’ (July 1957) (National Library of Australia: N 639.309945). For historical commercial fisheries in South Africa, see 'Fishing Industry. Shark Fishing Industry. General', HEN 1497 180/1/3 Part 1, 1921-1930, SANA; 'Leather Made from Shark Skins', Cape Times, 9 April 1929.
} 
Resulting in part from shark management strategies exchanged between Australian and South African officials, these declining catch records reveal the existence of a transboundary marine environmental history that spanned the Pacific and Indian Ocean worlds. This history involved movements of both ideas and organisms. Beginning in the early 1900s, Australian and South African citizens traded shark management technologies, ranging from comparatively benign fences to meshing and drum-line programs of varying degrees of destructiveness, with major repercussions for large shark populations in both countries' waters. Meanwhile, the sharks themselves also passed in and out of the zones patrolled by each nation, with some sharks even migrating between the two coastal areas. When meshing or drum-line programs destroyed these manifestations of mobile nature, they ensured that these migratory fish would not return to the guarded waters at some future date. The diminishments indicated by meshing program catch records might have appeared to be local. But in reality they would have also extended in some form out into the distant waters through which the eliminated sharks had previously passed. ${ }^{99}$

The stock decreases resulting from bather-safety programs mirrored a broader reduction in many shark species globally. Over the last few decades, numerous researchers have warned that world shark populations have fallen under intensifying fishing pressure, and that, without rapid intervention, large numbers of these species will experience catastrophic declines. ${ }^{100}$ This escalation has resulted partly from the shark fin industry, which surged with the increasing purchasing power of Chinese consumers, beginning in the 1980s. But this rising fishing pressure is also due to growing demands for cheap protein, often in the developing world, especially in regions where conventional food fisheries have already been depleted. ${ }^{101}$ New fishing technologies have also allowed harvesters to target shark species that were formerly inaccessible. Since 1950, annual world shark harvests have tripled to around 800,000 tonnes as a result of these various developments. ${ }^{102}$

Responding to warnings from numerous fisheries scientists, the United Nations' Food and Agriculture Organization established an International Plan of Action for the Conservation and Management of Sharks in 1998. Most member nations with large shark fisheries have agreed to participate, but enforcement has proved challenging. Moreover, the biology of sharks makes them difficult to manage and

99 John D. Stevens, 'Epipelagic Oceanic Elasmobranchs', Sharks and Their Relatives, ed. Carrier et al., 4, 15; S. Tanaka et al., 'Age, growth, and genetic status of the white shark', 548-56.

100 Julia K. Baum et al., 'Collapse and Conservation of Shark Populations in the Northwest Atlantic', Science 299, no. 5605 (17 January 2003): 389-92; Alberto Barausse et al., 'The role of fisheries and the environment in driving the decline of elasmobranchs in the northern Adriatic Sea', ICES Journal of Marine Science 71, no. 7 (2014): 1594, doi.org/10.1093/icesjms/fst222.

101 Klimley, Biology of Sharks and Rays, 438.

102 L. J. V. Compagno, 'Shark Exploitation and Conservation' in Elasmobranchs as Living Resources: Advances in the Biology, Ecology, Systematics, and the Status of the Fisheries NOAA Technical Report NMFS 90, ed. Harold L. Pratt et al. (Seattle, WA: US Dept of Commerce, 1990), 391; X. N. Verlecar et al., 'Shark hunting—an indiscriminate trade endangering elasmobranchs to extinction', Current Science 92, no. 8 (25 April 2007): 1078-82. 
conserve. Ecologists distinguish between 'R-selected' and 'K-selected' species. The former reproduce prolifically and have short life spans, allowing them to rebound rapidly from exploitation under ideal conditions. The latter produce few young and mature slowly, enabling them to thrive in undisturbed conditions, but rendering them poorly adapted to recover from population declines. Many shark species, including all large ones, fall into the latter category. ${ }^{103}$ This combination of economic, legislative and biological factors has led numerous scholars to warn that many species of sharks will face dramatic collapses in the next few decades. Fisheries scientists have already reported some instances of local extinctions. ${ }^{104}$

Adding to the urgency of the situation, researchers have demonstrated that the removal of apex predators, such as large sharks, from an ecosystem often results in a process dubbed 'trophic cascading'. This involves shifts in population ratios and feeding patterns as the organisms within each level of a food web adjust to new opportunities and perils. For instance, scholars speculate that in some cases the removal of large sharks that consumed small sharks may have resulted in an increase in the latter. In turn, growing populations of small sharks may have competed with and consumed stocks of commercially valuable fish species, causing their numbers to plummet. ${ }^{105}$ Although we might not recognise it, the transoceanic history of Australian and South African shark management has likely transformed marine ecosystems in ways that extend far beyond shark populations.

\section{Conclusion}

The recent surge in attention to the plight of sharks can create the impression that humans have only begun to affect shark stocks in the last few decades, and it is true that harvests have greatly increased since the 1980s. Yet, as fisheries scientist Daniel Pauly has warned us, we must be careful not to fall prey to 'shifting baseline' syndrome. ${ }^{106}$ This misconception occurs when we assume that, prior to an identified

\footnotetext{
103 Verlecar, 'Shark Hunting', 1078.

104 Compagno, 'Shark Exploitation and Conservation', 412; Alastair V. Harry et al., 'Evaluating catch and mitigating risk in a multispecies, tropical, inshore shark fishery within the Great Barrier Reef World Heritage Area', Marine and Freshwater Research 62, no. 6 (June 2011): 710-11, doi.org/10.1071/mf10155; J. K. Carlson et al., 'Relative Abundance and Size of Coastal Sharks Derived from Commercial Shark Longline Catch and Effort Data', Journal of Fish Biology 80 (2012): 1749-64; Barausse et al., 'The role of fisheries and the environment', 1593, doi.org/10.1111/j.1095-8649.2011.03193.x.

105 Manon Osseweijer, 'A Toothy Tale: A Short History of Shark Fisheries and Trade in Shark Products in Twentieth-Century Indonesia', in A World of Water: Rain, Rivers, and Seas in Southeast Asian Histories, ed. Peter Boomgaard (Leiden: KITLV, 2007), 114; Klimley, Biology of Sharks and Rays, 443; Hugo Bornatowski et al., 'Ecological Importance of Sharks and Rays in a Structural Foodweb Analysis in Southern Brazil', ICES Journal of Marine Science 71, no. 7 (2014): 1586-92, doi.org/10.1093/icesjms/fsu025.

106 Daniel Pauly, 'Anecdotes and the Shifting Baseline Syndrome of Fisheries', Trends in Ecology and Evolution 10, no. 10 (October 1995): 430. Also see W. Jeffrey Bolster, The Mortal Sea: Fishing the Atlantic in the Age of Sail (Cambridge, MA: Harvard University Press, 2012), 1; David J. Starkey, Poul Holm and Michaela Barnard, Oceans Past: Management Insights from the History of Marine Animal Populations (London: Earthscan, 2008), xv.
} 
change, the environment existed in a pristine or natural state. Such thinking prevents us from recognising that human transformations of the environment often extend much further back in time. In the case of Australia's and South Africa's shark populations, bather-safety programs have been deliberately obliterating these fish since the 1930s in the former country's waters and the 1950s in the latter's.

These significant environmental changes resulted directly from the attempts of policymakers to establish and enforce barriers regulating the flow of mobile nature. The history of shark management in Australia and South Africa provides new insights into this theme. This story reveals that future research on mobile nature may need to adopt broader frames of reference, shifting from discussions of the 'trans-boundary' and 'transnational' to analyses of the 'transoceanic' and 'transcontinental'. Recent work by Gregory Barton and Brett Bennett on global forestry networks similarly demonstrates this requirement. The history of shark management also highlights the manner in which efforts to regulate and discipline nature have historically intersected with desires to administer and control people, with major ramifications for both. Finally, this topic demonstrates how shifting perceptions of particular species, and of the environment more broadly, have forced policymakers to rethink the placement and enforcement of boundaries regulating interactions between people and nature. To understand contemporary environmental issues, we need to adopt a new perspective, one which identifies obscured connections spanning further back in time, ranging across broader geographic scales, and transcending tidy demarcations between the human and natural worlds. This study has made an attempt in that direction, but many sprawling environmental histories remain to be chronicled. ${ }^{107}$

107 Gregory Barton, Empire Forestry and the Origins of Environmentalism (Cambridge: Cambridge University Press, 2007); Brett Bennett, Plantations and Protected Areas: A Global History of Forest Management (Cambridge, MA: MIT Press, 2015). 
This text is taken from International Review of Environmental History, Volume 3, Issue 2, 2017, edited by James Beattie, published 2017 by ANU Press, The Australian National University, Canberra, Australia.

dx.doi.org/10.22459/IREH.03.02.2017.02 